\title{
The Interpretation of Underground Water Physical Parameters of Housing in the Region of Asahan Indah Palm Oil Factory Area Rokan Hulu District
}

\author{
M. Juandi \\ Department of Physics Math and Science Faculty, University of Riau, Pekanbaru, Indonesia \\ Email: juandi_m@rocketmail.com, juandi@lecturer.unri.ac.id
}

How to cite this paper: Juandi, M. (2018) The Interpretation of Underground Water Physical Parameters of Housing in the Region of Asahan Indah Palm Oil Factory Area Rokan Hulu Distric. Open Journal of Modern Hydrology, 8, 119-125.

https://doi.org/10.4236/ojmh.2018.84009

Received: July 28, 2018

Accepted: September 22, 2018

Published: September 25, 2018

Copyright $\odot 2018$ by author and Scientific Research Publishing Inc. This work is licensed under the Creative Commons Attribution International License (CC BY 4.0).

http://creativecommons.org/licenses/by/4.0/

\begin{abstract}
The research has been conducted to analyze the distribution of underground water physical parameters of the housing around Asahan Indah palm oil factory area Rokan Hulu District with radial method within \pm 300 meters radius from the factory location. The levels of underground water physical parameters include conductivity, resistivity, and salinity measured based on coordinate points amounted of 50 points. The data obtained from the measurement results were then inputted into "surfer 11 " software to be processed in order to obtain the contour map of underground water physical parameters level. The results of this research indicated that the highest conductivity level came from the ring well type with 5 meter depth; it was $0.0964(1 / \mathrm{ohm} \cdot \mathrm{m})$ exceeded the standard threshold of underground water quality standard and the lowest conductivity was $0.00342(1 / \mathrm{ohm} \cdot \mathrm{m})$ which came from a ring well type with 10 meter depth. The lowest resistivity level was $10.37 \mathrm{ohm} \cdot \mathrm{m}$ which came from the ring well type with 5 meter depth and the highest was $292.4 \mathrm{ohm} \cdot \mathrm{m}$ which came from the ring well with 10 meter depth. The highest salinity level was $448 \mathrm{mg} / \mathrm{l}$ which exceeded the baseline threshold of underground water quality which came from the ring well type with 5 meter depth and the lowest was $175 \mathrm{mg} / \mathrm{l}$ from the ring well with 10 meter depth. The results of this research found that underground water in wells with 5 meters depth has been polluted with palm oil waste and at the depth of 10 meters, it has not been contaminated.
\end{abstract}

\section{Keywords}

Conductivity, Resistivity, Salinity, Palm Factory Waste, Underground Water 


\section{Introduction}

The need of clean water sourced from underground water in certain areas increases from year to year along with population growth and development activities [1]. In order to serve the needs of clean water sourced from underground water, it is needed to understand the potential of groundwater both in quantity and quality [2]. Human activity on the utilization of natural resources in this case is the palm oil processing industry can cause soil contamination. Generally, the waste discharged into the environment affects soil conditions and leads to a decrease in the quality and aesthetic value of the environment [3]. The pollution of underground environment caused by palm oil waste is one of the problems faced by developing countries like Indonesia [4]. This pollution will also affect the underground water itself. The small porosity and permeability factor in the lithology of the research area causes difficulties for the waste to permeate [5].

The previous research has shown that palm oil factory can produce liquid waste [6]. The waste may contaminate the underground water system as indicated by changes in the value of physical water parameters such as conductivity, resistivity and salinity [7]. The theoretical investigation can be carried out that the presence of waste can affect the metal content in which the metal has a conductive value because the metal is conductive. The research to determine the physical parameters of groundwater such as conductivity, resistivity, and salinity has been largely carried out by previous researches [8].

Conductivity, resistivity, and salinity are physical parameters that can provide description of the water quality itself. The resistivity of a material is the ability of a material to inhibit the flow of electricity in it, where electricity only flows in a conductive material. Conductivity is the opposite of resistivity; it is the ability of a material to conduct an electric current. The value of underground water conductivity is between $0.003-0.021 / \Omega \mathrm{m}$ [9], the value of underground water resistivity is between $30-200 \Omega \mathrm{m}$ [10], and the salinity value of proper underground water consumption should not exceed $400 \mathrm{mg} / \mathrm{l}$ [11].

This research was conducted in the area around Asahan Indah palm factory Rokan Hulu District in the radius of \pm 300 meter at 50 coordinate points with radial method. This research aimed to determine the distribution patterns of underground water physical parameters and contamination levels that occur around Asahan Indah palm oil factory Rokan Hulu District.

\section{Research Method}

The research method used in this research was radial method. The tools and materials used in this research were GPS, EC, container, hand refractometer, surfer software, underground water sample, measuring cup, and laptop.

The first thing to do was determining the coordinate points by using GPS. The coordinate points spread around the factory within a radius of \pm 300 meters from the palm factory location, and then water sampling was conducted from the ring wells with 0.5 litres. The samples taken from several location points around the 
palm factory were later taken to the Soil Science Laboratory by using a container for measuring its conductivity and salinity levels and calculating the conductivity and salinity levels, also its resistivity level. The procedure of measuring the conductivity was inserting the EC tool into the water sample with a volume of 0.5 litres and it was carried out 5 times in order to get the standard deviation. The obtained conductivity value was later used to calculate the resistivity using the equation of $\rho=1 / \sigma$ where $\rho$ is resistivity and $\sigma$ is conductivity. The salinity was measured by dripping groundwater samples on a hand refractometer device.

\section{Result and Discussion}

The following was the contour result of conductivity, resistivity and salinity level of underground water in the area around the factory within a radius of 300 meters. The $\mathrm{x}$-axis and $\mathrm{y}$-axis represent the location coordinates and the color scale indicates the conductivity, salinity, and resistivity level of the underground water. In the blue zone contour map results are located in the area around the factory because the majority of people in this zone have used the ring well type with 10 meter depth, and for the red zone was far away from the factory because the people in this zone used the ring well type with 5 meter depth. The level of conductivity, resistivity and salinity in the area around the factory which has exceeded the threshold was in the red area in which in that point the salinity value has been contaminated, it is in the ring well with 5 meters depth 3 .

Figure 1 shows the contours of underground water conductivity level in the area around Asahan Indah palm factory Rokan Hulu District in two-dimensional view (2D). The minimum conductivity value resides in the underground water source of ring well with 10 meter depth amounted of $0.00342(1 / \mathrm{ohm} \cdot \mathrm{m})$ and the maximum conductivity value is in the underground water source of ring well with 5 meter depth amounted of $0.0964(1 / \mathrm{ohm} \cdot \mathrm{m})$. Figure 2 shows the contours of underground water resistivity level in the area around Asahan Indah palm

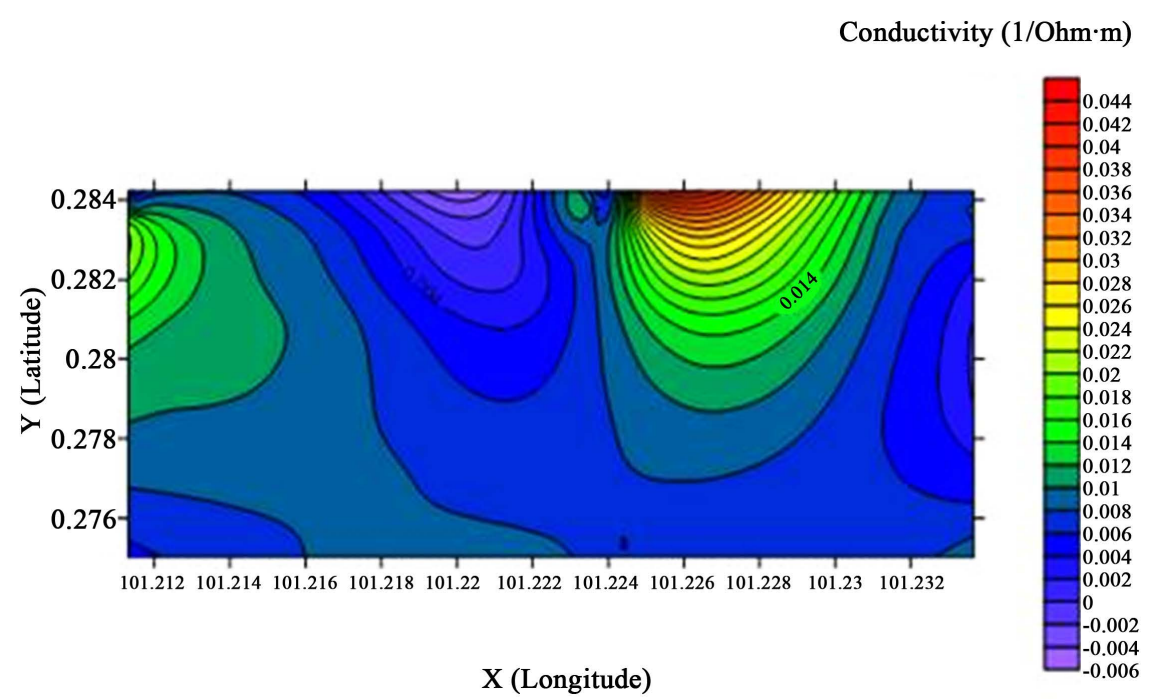

Figure 1. Contours of underground water conductivity level. 


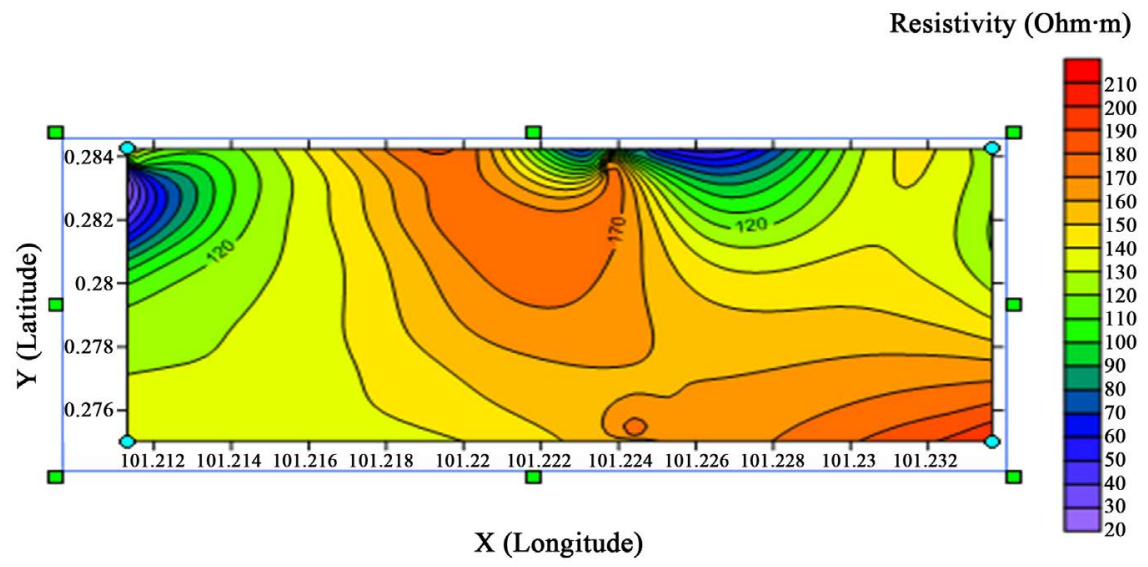

Figure 2. Contour of underground water resistivity level.

factory Rokan Hulu District in two dimensional view (2D). This resistivity value is the inverse of the conductivity value where the largest resistivity value is $292.4 \mathrm{ohm} \cdot \mathrm{m}$ and the smallest resistivity value is $10.37 \mathrm{ohm} \cdot \mathrm{m}$. Figure 3 shows the contours of underground water salinity levels in the area around the factory in a two-dimensional view (2D). In the figure, it can be seen that for the minimum salinity value comes from the ring well type with 10 meter depth amounted of $175 \mathrm{mg} / \mathrm{l}$ and for the maximum salinity value comes from the ring well type with 5 meter depth amounted of $2700 \mathrm{mg} / \mathrm{l}$. The ring well type with 5 meter depth has a major impact due to factory waste compared to a ring well type with 10 meter depth because the 5 meter ring well is much shallower than the ring well type with 10 meter depth.

Figure 4 shows that the conductivity values of SC43, SC45, SC49 (ring wells) exceed the threshold of the underground water quality standard so that they are identified as being contaminated. The identification showed that a ring well with 5 meter depth was contaminated compared to a ring well with 10 meter depth due to the shallow of a 5 meter ring well compared to a 10 meter ring well. The 10 meter ring well has not been contaminated due to depth factor; the average ring well is 10 meters depth. So the waste cannot seep into the 10 meters ring well. The physical factors that can affect the waste infiltration are porosity and soil permeability. The location of the research indicates that the soil lithology is composed of gravel, crust, sand and clay spreads, this can cause very small porosity and permeability values in the presence of clay, wherein the clay is impermeable. The permeability is directly proportional to the porosity where the smaller the permeability of the soil the smaller the porosity so that the waste is difficult to seep into the 10 meter ring well.

Figure 5 shows that there is no resistivity value that exceeds the maximum limit of underground water quality standard but the resistivity value at SC25 exceeds the underground water quality standard threshold and SC45, SC49 has not achieved the water quality standard, means that it does not reach the minimum threshold of underground water quality standard. The small porosity and permeability factor in the lithology of the research area causes difficulties for the 


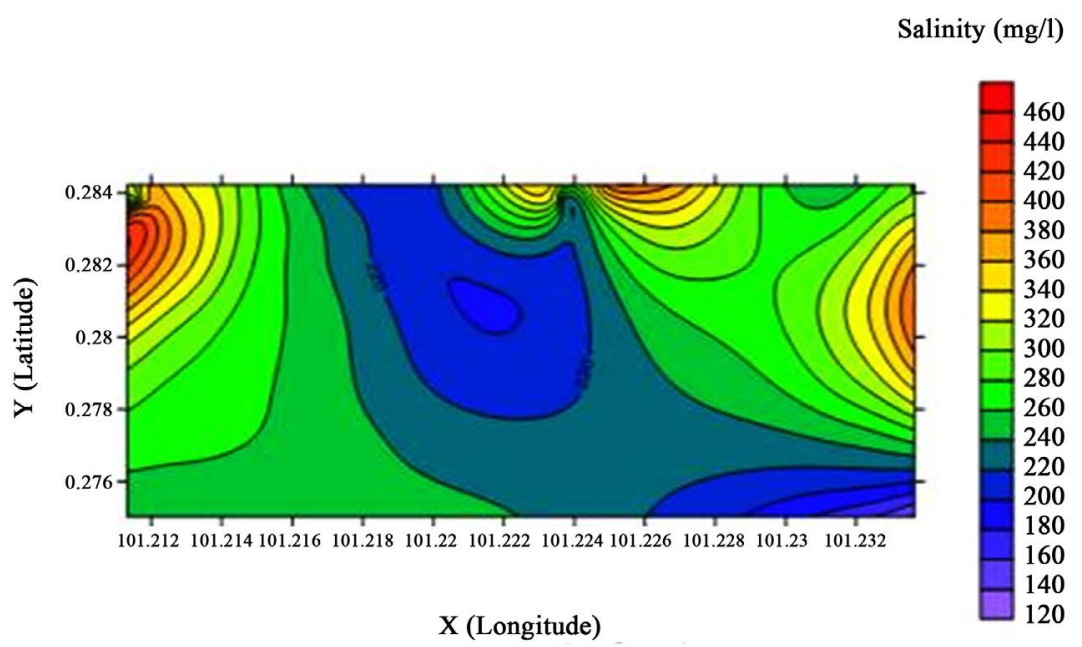

Figure 3. Contours of underground water salinity level.

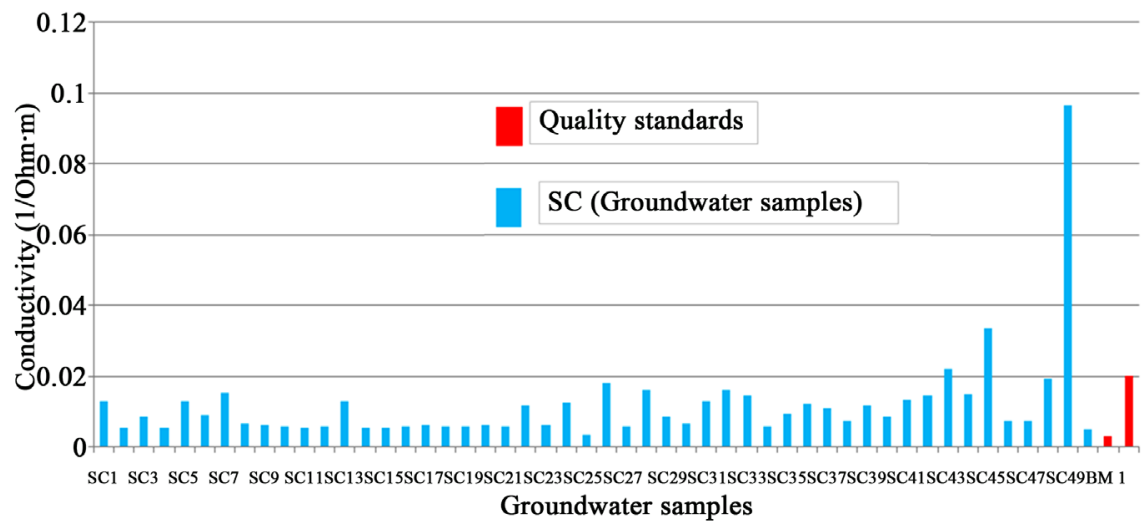

Figure 4. Graph of conductivity level and underground water quality standard.

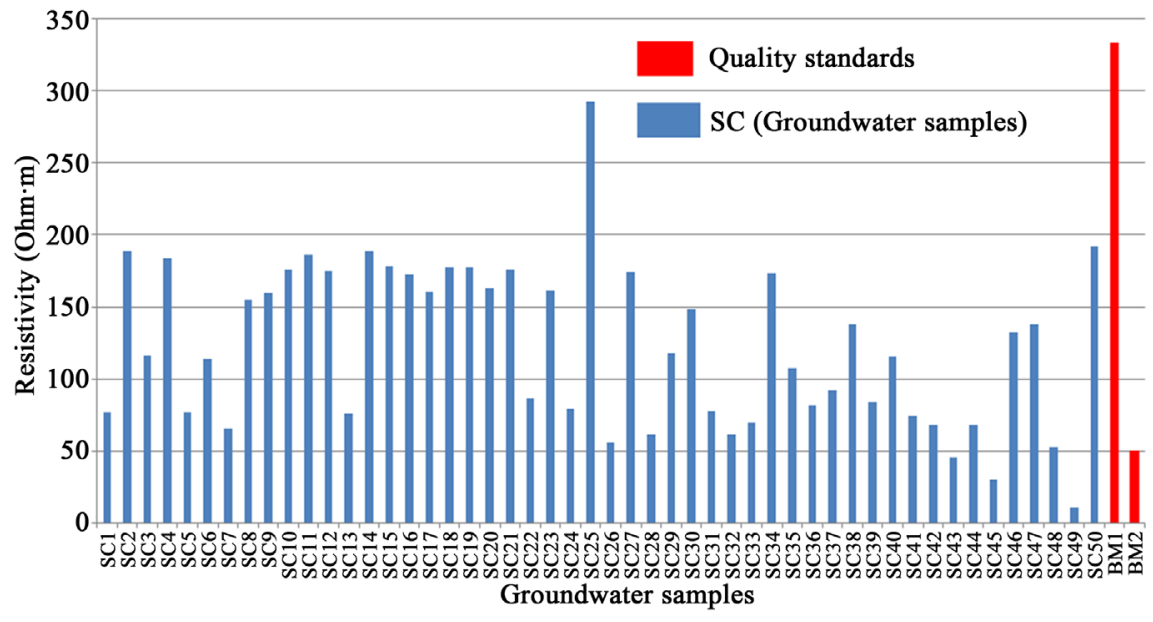

Figure 5. Graphic of resistivity level and underground water quality standard.

waste to permeate, this conductive waste causes small underground water resistivity, so that in the ring wells having an average depth of 8 meters, the resistivity is very small due to the conductive waste seepage. Figure 6 shows the salinity 


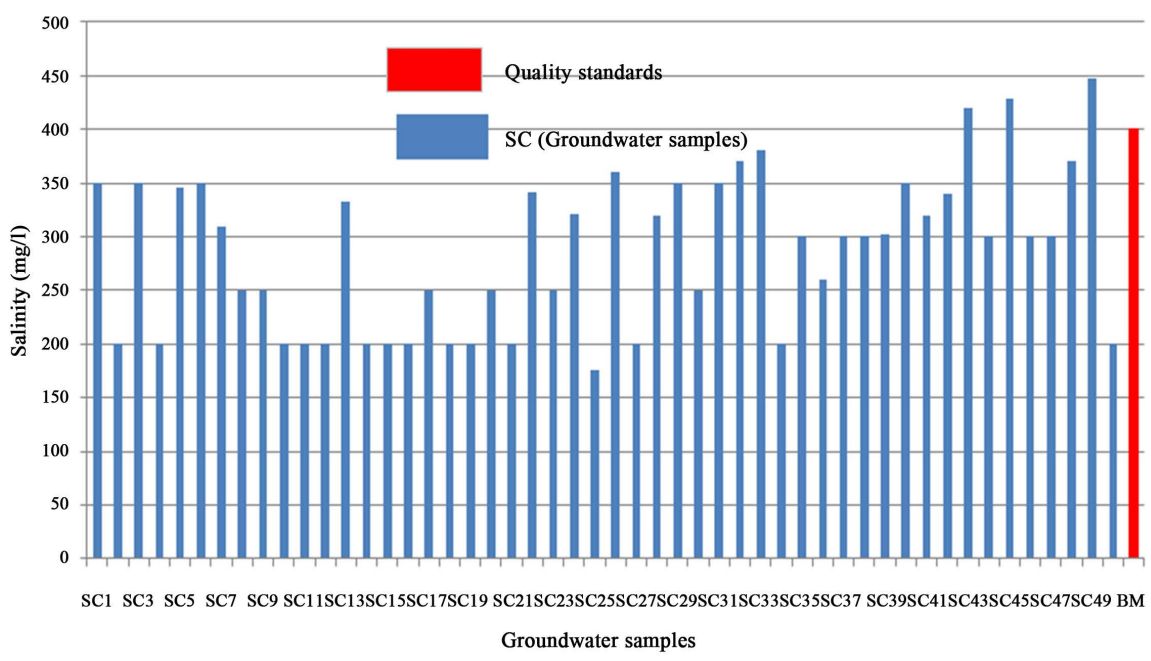

Figure 6. Graph of salinity level and underground water quality standard.

levels in SC43, SC45 and SC49 (ring wells) exceeding the maximum limit of underground water quality standards to identify the contamination at points SC43, SC45 and SC49. The small porosity and location permeability factors is due to the research location with clay lithology resulted in the difficulty for waste to permeate into a 5 meter ring well than into a 10 meter ring well.

\section{Conclusions}

Based on the results of research that has been conducted, it can be concluded that:

1) The highest conductivity level measurement results were from the ring well with 5 meter depth amounted of $0.0964(1 / \mathrm{ohm} \cdot \mathrm{m})$ and the lowest were from the ring well with 10 meter depth amounted of $0.00342(1 / \mathrm{ohm} \cdot \mathrm{m})$.

2) The highest resistivity level came from the ring well with 10 meter depth amounted of $292.4 \mathrm{ohm} \cdot \mathrm{m}$ and the lowest is from the ring well with 5 meter depth amounted of $10.37 \mathrm{ohm} \cdot \mathrm{m}$.

3) The highest salinity level came from the ring well with 10 meter depth amounted of $448 \mathrm{mg} / \mathrm{l}$ and the lowest was from the ring well with 5 meter depth amounted of $175 \mathrm{mg} / \mathrm{l}$.

4) Profile of conductivity distribution from the north to the south and from the west to the east has tendency to decrease.

5) Profile of resistivity level distribution from the north to the south and from the west to the east has tendency to increase.

6) Profile of salinity distribution from the north to the south and from the west to the east has tendency to decrease.

\section{Conflicts of Interest}

The author declares no conflicts of interest regarding the publication of this paper. 


\section{References}

[1] Juandi, M. (2017) Sustainability Model for Unconfined Aquifers. International Journal of Science and Applied Technology, 1, 8-14. http://ijsat.unri.ac.id/index.php/IJSAT/article/view/12

[2] Juandi, M. and Syahril, S. (2017) Empirical Relationship between Soil Permeability and Resistivity, and Its Application for Determining the Groundwater Gross Recharge in Marpoyan Damai, Pekanbaru, Indonesia. Water Practice and Technology, 12, 660-666. https://doi.org/10.2166/wpt.2017.069

[3] Sudrajat (2006) Mengelola Sampah Kota. Penebar Swadaya, Jakarta.

[4] Djajadiningrat, S.T. and Harsono, H. (1991) Penilaian Secara Cepat Sumber-Sumber Pencemaran Air, Tanah, Udara. Gadjah Mada University Press, Yogyakarta.

[5] Juandi, M. (2016) Quantitative Models to Study the Soil Porosity as Function of Soil Resistivity. Open Journal of Modern Hydrology, 6, 253-262. https://doi.org/10.4236/ojmh.2016.64020

[6] Juandi, M. (2010) Penyelidikan Pola Sebaran Limbah Karet Bawah Permukaan Tanah Dengan Metode Geolistrik. Jurnal Ilmu Lingkungan, 1, 36-45.

[7] Gabriel, J.F. (2001) Fisika Lingkungan. Hipokrates, Jakarta

[8] Natsir, N.A. (2014) Analisis Kandungan MPN Coliform Fecal Pada Sumur Galian Dan Sumur Bor Di RT 01 Desa Batu Merah Kecamatan Sirimau Kota Ambon. Jurnal Fikratuna, 1, 6.

[9] Davis, S.N. and Wiest, R.J.M. (1996) Hydrogeology. John Willey and Sons Inc., New York.

[10] Richard, E.C. (2002) Physics for Geologists. 2nd Edition, CRC Press, London.

[11] Ginting, I.I. (2014) Pemetaan Salinitas Pada Sumur Bor Di Kelurahan Belawan II Kecamatan Medan Belawan. 